2 Freedman B. Equipoise and the ethics of clinical research. $N$ Engl J Med 1987;317:141-5.

3 Peto R, Baigent C. Trials: the next 50 years. Large scale randomised evidence of moderate benefits. BMJ 1998;317:1170-1.

4 Edwards SJ, Lilford RJ, Braunholtz DA, Jackson JC, Hewison J, Thornton $\mathrm{J}$. Ethical issues in the design and conduct of randomised controlled trials. Health Technol Assess 1998;2:i-vi,1-132.

5 Hellman S, Hellman DS. Of mice but not men. Problems of the randomized clinical trial. $N$ Engl J Med 1991;324:1585-9.

6 Fried C. Medical experimentation: personal integrity and social policy. New York: American Elsevier, 1974

7 Marquis D. Leaving therapy to chance. Hastings Cent Rep 1983;13:40-7.

8 Djulbegovic B, Lacevic M, Cantor A, Fields KK, Bennett CL, Adams JR, et Jjulbegovic B, Lacevic M, Cantor A, Fields KK, Bennett CL, Adams JR, et
al. The uncertainty principle and industry-sponsored research. Lancet 2000;356:635-8.

9 Lau J, Antman EM, Jimenez-Silva J, Kupelnick B, Mosteller F, Chalmers TC. Cumulative meta-analysis of therapeutic trials for myocardial infarc tion. N Engl J Med 1992;327:248-54.
10 Chalmers I. What is the prior probability of a proposed new treatment being superior to established treatments? BMJ 1997;314:74-5.

11 Gilbert JP, McPeek B, Mosteller F. Statistics and ethics in surgery and Gilbert JP, McPeek B, Mosteller
anesthesia. Science 1977;198:684-9.

12 Machin D, Stenning SP, Parmar MK, Fayers PM, Girling DJ, Stephens RJ, et al. Thirty years of Medical Research Council randomized trials in solid tumours. Clin Oncol 1997;9:100-14.

13 Als-Nielsen B, Chen W, Gluud C, Kjaergard LL. Association of funding and conclusions in randomized drug trials: a reflection of treatment effect or adverse events? JAMA 2003;290:921-8.

14 Lee SJ, Zelen M. Clinical trials and sample size considerations: another perspective. Stat Sci 2000;15:95-110.

15 Chlebowski RT, Lillington LM. A decade of breast cancer clinical investigation: results as reported in the program/proceedings of the American Society of Clinical Oncology.J Clin Oncol 1994;12:1789-95. (Accepted 2 April 2004)

doi $10.1136 /$ bmj. 38118.685289 .55

\title{
Hospital admission for acute pancreatitis in an English population, 1963-98: database study of incidence and mortality
}

\author{
Michael J Goldacre, Stephen E Roberts
}

Unit of Health-Care Epidemiology, Department of Public Health, University of Oxford, Old Road, Oxford OX3 7LF

Michael J Goldacre professor of public health

Stephen E Roberts university research lecturer

Correspondence to: M Goldacre michael.goldacre@ dphpc.ox.ac.uk

\section{Abstract}

Objectives To investigate trends in the incidence of acute pancreatitis resulting in admission to hospital, and mortality after admission, from 1963 to 1998 .

Design Analysis of hospital inpatient statistics for acute pancreatitis, linked to data from death certificates.

Setting Southern England.

Subjects 5312 people admitted to hospital with acute pancreatitis.

Main outcome measures Incidence rates for admission to hospital, case fatality rates at 0-29 and 30-364 days after admission, and standardised mortality ratios at monthly intervals up to one year after admission.

Results The incidence of acute pancreatitis with admission to hospital increased from 1963-98: age standardised incidence rates were 4.9 per 100000 population in 1963-74, 7.7 in 1975-86, and 9.8 in 1987-98. Age standardised case fatality rates within 30 days of admission were $14.2 \%$ in $1963-74,7.6 \%$ in $1975-86$, and $6.7 \%$ in $1987-98$. From $1975-98$, standardised mortality ratios at 30 days were 30 in men and 31 in women (compared with the general population of equivalent age in the same period $=1$ ), and they remained significantly increased until month 5 for men and month 6 for women.

Conclusions Incidence rates for acute pancreatitis with admission to hospital rose in both men and women from 1963 to 1998, particularly among younger age groups. This probably reflects, at least in part, an increase in alcoholic pancreatitis. Mortality after admission has not declined since the 1970s. This presumably reflects the fact that no major innovations in the treatment of acute pancreatitis have been introduced. Pancreatitis remains a disease with a poor prognosis during the acute phase.

\section{Introduction}

Acute pancreatitis has become increasingly common in Western countries in recent decades.$^{1-8}$ When severe it has a high risk of mortality, but few studies have quantified mortality after hospital admission in defined populations and time periods. ${ }^{4-10}$ We investigated long term trends in the incidence of acute pancreatitis with admission to hospital and in mortality after admission.

\section{Methods}

\section{Study population}

We used the Oxford record linkage study, which comprises anonymised hospital statistical records linked to death certificate data (population of 0.35 million from 1963, 0.9 million from 1968, 1.8 million from 1975, and 2.5 million from 1987). We selected all admissions for acute pancreatitis as the principal diagnosis recorded in the database. We identified each patient's first admission and any death that followed it within 365 days. At the end of each 365 day period we included any subsequent admission for a "new" period of one year follow up. The database covered admissions from 1963 to 31 March 1998 with linkage to death certificates to 31 March 1999

\section{Statistical methods}

We used admissions for acute pancreatitis as the numerator and the total resident population in the area covered by the data as the denominator to calculate incidence rates for admission to hospital. We used the direct method and the standard European population to standardise trends in incidence rates. We used admissions for acute pancreatitis as the denominator and deaths from any cause after admission as the numerator to calculate case fatality rates. Our standard population to standardise trends in case fatality rates directly was the total population of patients admitted for acute pancreatitis from 1963 to 1998 . We used the indirect method, applying the age and sex specific

Additional figures $A$ and $B$ and table $A$ are on bmj.com 
Table 1 Age specific and age standardised hospital admission rates for acute pancreatitis per 100000 population, 1963-74, 1975-86 and 1987-98

\begin{tabular}{|c|c|c|c|c|c|c|}
\hline \multirow[b]{2}{*}{ Age group } & \multicolumn{2}{|c|}{$1963-74$} & \multicolumn{2}{|c|}{$1975-86$} & \multicolumn{2}{|c|}{ 1987-98 } \\
\hline & $\begin{array}{c}\text { No of } \\
\text { admissions }\end{array}$ & $\begin{array}{l}\text { Rate per } 100000 \\
\text { population }(95 \% \mathrm{CI})\end{array}$ & $\begin{array}{c}\text { No of } \\
\text { admissions }\end{array}$ & $\begin{array}{c}\text { Rate per } 100000 \\
\text { population }(95 \% \mathrm{Cl})\end{array}$ & $\begin{array}{c}\text { No of } \\
\text { admissions }\end{array}$ & $\begin{array}{c}\text { Rate per } 100000 \\
\text { population }(95 \% \mathrm{CI})\end{array}$ \\
\hline \multicolumn{7}{|l|}{ Men } \\
\hline$<35$ & 18 & 0.7 (0.4 to 1.1$)$ & 174 & 2.5 (2.1 to 2.9$)$ & 299 & 3.6 (3.2 to 4.0 ) \\
\hline $35-44$ & 27 & 5.0 (3.1 to 6.8 ) & 126 & 7.6 (6.3 to 9.0$)$ & 295 & 13.8 (12.2 to 15.3$)$ \\
\hline $45-54$ & 41 & 8.4 (5.8 to 11.0) & 177 & 12.6 (10.8 to 14.5$)$ & 284 & 15.7 (13.9 to 17.5$)$ \\
\hline $55-64$ & 43 & 10.5 (7.4 to 13.7$)$ & 176 & 14.4 (12.2 to 16.5$)$ & 251 & 18.6 (16.3 to 20.9) \\
\hline $65-74$ & 34 & 13.5 (9.0 to 18.1) & 199 & 23.1 (19.9 to 26.3) & 253 & 25.4 (22.2 to 28.5) \\
\hline $75+$ & 28 & 21.7 (13.6 to 29.9 ) & 131 & 33.5 (27.4 to 39.6 ) & 214 & 35.5 (30.6 to 40.4$)$ \\
\hline All ages & 191 & 5.2 (4.5 to 5.9$)$ & 983 & 8.6 (8.1 to 9.2 ) & 1596 & 11.2 (10.6 to 11.7$)$ \\
\hline \multicolumn{7}{|l|}{ Women } \\
\hline$<35$ & 18 & 0.8 (0.4 to 1.2$)$ & 128 & 1.9 (1.6 to 2.2$)$ & 219 & 2.8 (2.4 to 3.1$)$ \\
\hline $35-44$ & 18 & 3.6 (1.9 to 5.3) & 81 & 5.1 (4.0 to 6.2) & 162 & 7.7 (6.5 to 8.9) \\
\hline $45-54$ & 20 & 4.1 (2.3 to 5.9$)$ & 89 & 6.5 (5.1 to 7.8$)$ & 185 & 10.6 (9.0 to 12.1$)$ \\
\hline $55-64$ & 49 & 11.1 (8.0 to 14.2) & 157 & 12.3 (10.3 to 14.2 ) & 194 & 14.4 (12.4 to 16.4$)$ \\
\hline $65-74$ & 50 & 14.9 (10.8 to 19.0 ) & 208 & 19.8 (17.1 to 22.5) & 250 & 21.3 (18.7 to 24.0) \\
\hline $75+$ & 46 & 19.5 (13.8 to 25.2) & 285 & 35.2 (31.0 to 39.3) & 373 & 34.2 (30.7 to 37.7$)$ \\
\hline All ages & 201 & 4.5 (3.9 to 5.2$)$ & 948 & 6.7 (6.3 to 7.2$)$ & 1383 & 8.4 (7.9 to 8.8$)$ \\
\hline Total $^{\star}$ & 392 & 4.9 (4.4 to 5.4$)$ & 1931 & 7.7 (7.3 to 8.0) & 2979 & 9.8 (9.4 to 10.1) \\
\hline
\end{tabular}

The International Classification of Diseases (ICD) code used for acute pancreatitis was 587.0 in the 7 th revision, 577.0 in ICD-8 and ICD-9, and K85 in ICD-10.

${ }^{*}$ The ages of 10 people were not known.

Table 2 Case fatality rates per 100 patients, adjusted for age groups and sex, with odds ratios for the case fatality rates derived through logistic regression analysis, at 0-29 days and 30-364 days after hospital admission for acute pancreatitis, 1963-74, 1975-86, and 1987-98

\begin{tabular}{|c|c|c|c|c|c|c|c|}
\hline \multirow[b]{2}{*}{ Time period } & \multirow[b]{2}{*}{$\begin{array}{c}\text { No of } \\
\text { admissions }\end{array}$} & \multicolumn{3}{|c|}{$0-29$ days } & \multicolumn{3}{|c|}{$30-364$ days } \\
\hline & & $\begin{array}{l}\text { No of } \\
\text { deaths }\end{array}$ & $\begin{array}{l}\text { Case fatality rate }(95 \% \\
\text { CI) }\end{array}$ & Odds ratio $(95 \% \mathrm{Cl})$ & $\begin{array}{l}\text { No of } \\
\text { deaths }\end{array}$ & $\begin{array}{l}\text { Case fatality rate (95\% } \\
\text { CI) }\end{array}$ & Odds ratio $(95 \% \mathrm{Cl})$ \\
\hline 1963-74 & 396 & 55 & 14.2 (9.9 to 18.4$)$ & 1.00 & 25 & 5.6 (3.3 to 8.0$)$ & 1.00 \\
\hline 1975-86 & 1934 & 156 & 7.6 (6.4 to 8.8$)$ & 0.48 (0.34 to 0.68$)$ & 105 & 5.1 (4.2 to 6.1$)$ & 0.88 (0.56 to 1.41$)$ \\
\hline 1987-98 & 2982 & 193 & 6.7 (5.7 to 7.7$)$ & 0.41 (0.29 to 0.58$)$ & 146 & 5.1 (4.3 to 5.9 ) & 0.87 (0.55 to 1.37$)$ \\
\hline 1963-98 (total) & 5312 & 404 & 7.6 (6.9 to 8.4$)$ & & 276 & 5.2 (4.6 to 5.8$)$ & \\
\hline
\end{tabular}

death rates in the whole population of the region (the "standard" population) to the number of people admitted for acute pancreatitis in the equivalent age and sex strata to calculate standardised mortality ratios.

\section{Results}

Altogether 5312 people were admitted with acute pancreatitis; $2776(52.3 \%)$ were men. The mean age of the patients was 56.3 (SD 19.2) years overall (men 53.2 (SD 18.0) years, women 59.7 (SD 19.8) years). The age of the patients admitted increased significantly over the study period $\left(\chi^{2}{ }_{1}\right.$ test for trend $8.1, \mathrm{P}=0.004$ for men; and $\chi_{1}^{2}$ test for trend 15.1, $\mathrm{P}<0.001$ for women). Excluding all readmissions within one year of a previous admission for acute pancreatitis, 4778 people $(89.9 \%)$ were admitted on only one occasion, 406 $(7.6 \%)$ were admitted twice, and $128(2.4 \%)$ were admitted on three or more occasions at least one year apart.

Incidence rates for both men and women increased substantially and significantly during the study period (table 1; figure A on bmj.com). Percentage increases in incidence rates were larger in younger than older age groups. Incidence rates also increased sharply with age (table 1).

Standardised case fatality rates at 0-29 and 30-364 days are summarised for the three periods 1963-74, 1975-86, and 1987-98 in table 2 and table A on bmj.com, and at 0-29 days for individual calendar years in figure $\mathrm{B}$ on bmj.com. Case fatality in men declined through the late 1960s but not thereafter, and we found no evidence of a decline in women (figure B on bmj.com). From 1975 to 1998, within a month of admission, the case fatality rate was $7.1 \%$; at $30-364$ days it was $5.1 \%$ (table 3 ). Case fatality rates increased substantially with age (table 3 ). We found no significant difference between men and women in age adjusted case fatality rates (table 3 ).

At one month after hospital admission, mortality was 30 times higher in men and 31 times higher in women than that in the general populations of men and women of equivalent age from 1975 to 1998 (figure). At month 2, mortality was, respectively, eight and seven times higher. Mortality remained significantly elevated until month 5 for men and month 6 for women.

The underlying cause of death was acute pancreatitis in $314(46.2 \%)$ of 680 deaths within one year of admission, chronic pancreatitis in 11 , other or unspecified diseases of the pancreas (6), other diseases of the gastrointestinal system (76), malignant neoplasms of the pancreas (33), other neoplasms (48), diseases of the circulatory system (108), and various other causes (84).

\section{Discussion}

Acute pancreatitis remains a disease with high mortality: death rates in the first month after admission are 30 times higher than in the general population of the same age. Case fatality rates have not improved since the $1970 \mathrm{~s}$. 
Table 3 Case fatality rates per 100 patients, with odds ratios for the case fatality rates derived through logistic regression analysis, for the effects of age group and sex at 0-29 days and 30-364 days after hospital admission for acute pancreatitis, 1975-98

\begin{tabular}{|c|c|c|c|c|c|c|c|}
\hline & \multirow[b]{2}{*}{$\begin{array}{c}\text { No of } \\
\text { admissions }\end{array}$} & \multicolumn{3}{|c|}{ 0-29 day follow-up } & \multicolumn{3}{|c|}{ 30-364 day follow up } \\
\hline & & $\begin{array}{l}\text { No of } \\
\text { deaths }\end{array}$ & $\begin{array}{l}\text { Case fatality rate }(95 \% \\
\text { CI) }\end{array}$ & Odds ratio $(95 \% \mathrm{Cl})$ & $\begin{array}{l}\text { No of } \\
\text { deaths }\end{array}$ & $\begin{array}{l}\text { Case fatality rate }(95 \% \\
\text { CI) }\end{array}$ & Odds ratio $(95 \%$ Cl \\
\hline \multicolumn{8}{|l|}{ Age group*: } \\
\hline$<35$ & 820 & 15 & 1.8 (0.9 to 2.7) & 1.00 & 8 & 1.0 (0.3 to 1.6) & 1.00 \\
\hline $35-44$ & 664 & 10 & 1.5 (0.6 to 2.4$)$ & 0.82 (0.37 to 1.83 ) & 11 & 1.7 (0.7 to 2.6) & 1.69 (0.68 to 4.24$)$ \\
\hline $45-54$ & 735 & 20 & 2.7 (1.5 to 3.9) & 1.49 (0.76 to 2.93$)$ & 20 & 2.7 (1.5 to 3.9$)$ & 2.82 (1.23 to 6.43$)$ \\
\hline $55-64$ & 778 & 41 & 5.3 (3.7 to 6.9) & 2.99 (1.64 to 5.45) & 39 & 5.0 (3.4 to 6.6$)$ & 5.38 (2.50 to 11.6) \\
\hline $65-74$ & 910 & 73 & 8.0 (6.2 to 9.8$)$ & 4.72 (2.69 to 8.30$)$ & 68 & 7.4 (5.7 to 9.2) & 8.30 (3.96 to 17.4) \\
\hline $75+$ & 1003 & 190 & 18.9 (16.2 to 21.6) & 12.91 (7.55 to 22.1) & 105 & 10.5 (8.5 to 12.5$)$ & 12.31 (5.95 to 25.5) \\
\hline \multicolumn{8}{|l|}{ Sex*: } \\
\hline Male & 2583 & 161 & 7.5 (6.3 to 8.7) & 1.00 & 124 & 5.3 (4.4 to 6.3$)$ & 1.00 \\
\hline Female & 2333 & 188 & 6.5 (5.6 to 7.5$)$ & 0.88 (0.70 to 1.11$)$ & 127 & 4.7 (3.8 to 5.5) & $0.86(0.66$ to 1.11$)$ \\
\hline All patients & 4910 & 349 & 7.1 (6.4 to 7.8$)$ & & 251 & 5.1 (4.5 to 5.8$)$ & \\
\hline
\end{tabular}

*Age specific mortality is adjusted for sex, and sex specific mortality is adjusted for age group. The ages of 6 patients admitted from 1975-98 were not known.

\section{Limitations of the study}

Our study's main limitations are that little clinical information and no pathology data were available about individuals. It was therefore not possible to report on the evidence on which the diagnoses were based, to study treatment, or to distinguish between the two main aetiologies, biliary tract disease and alcoholic pancreatitis. The relative contribution of these two aetiologies varies between different places, over time, between men and women, and at different ages. For example, alcohol consumption is higher in young people than in elderly women, but pancreatitis is more common in elderly women. Acute pancreatitis among young people is more commonly alcohol related, whereas in elderly women it is mainly caused by biliary tract disease.

\section{Strengths of the study}

The main strengths of this study are that it is a large, population based analysis of more than 5000 cases. It shows long term trends in hospital admission rates and mortality after admission over a 36 year period, and it is based on systematic follow up through linkage to death certificate data.

\section{Comparison with other studies}

Almost all people who receive a diagnosis of acute pancreatitis will have been admitted to hospital. Our figures on admission rates are therefore a good

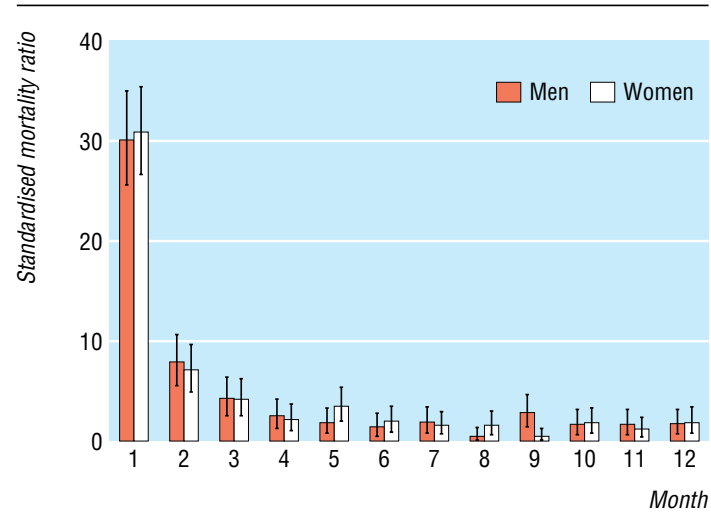

Standardised mortality ratios with 95\% confidence intervals at monthly intervals after hospital admission for acute pancreatitis in men and women, 1975-98. (Standardised mortality ratio in the general population $=1$ )

\section{What is already known on this topic}

The incidence of acute pancreatitis has increased in Britain in recent decades

Acute pancreatitis has a poor prognosis, although data on its incidence and prognosis in defined populations are sparse

\section{What this study adds}

Hospital admission rates in the population studied have doubled over the past 30 years

Increases in admission rates over time were greater in the younger age groups and, at least in part, probably represent an increase in alcoholic pancreatitis

Death rates in the first month after an attack are about 30 times higher than mortality in the general population of equivalent age

Case fatality rates have shown little or no improvement since the 1970 s

approximation of true, diagnosed incidence. A recent national study, covering a much shorter period of time than ours, reported an age standardised admission rate for acute pancreatitis in the whole of England that increased from 14.5 per 100000 in $1989-90$ to $20.7 / 100000$ in $1999-2000 .^{7}$ This is higher than in our study of the Oxford region. However, the national study used hospital episode statistics: these are based on finished consultant episodes of care, which are invariably higher than the actual numbers of people treated.

The authors of the English national study, ${ }^{7}$ and others, ${ }^{11}{ }^{12}$ have suggested that the rise in pancreatitis is probably, in particular, a rise in alcoholic pancreatitis related to increasing use of alcohol in the community. The similarities between the trend profiles for incidence of acute pancreatitis in our study, and those of increasing alcohol consumption ${ }^{713}$ and alcohol related deaths,${ }^{15}$ indicate an increase in alcoholic pancreatitis. However, the possibility exists that other factors, too, may have contributed to the rise. One possibility is an increase in the prevalence of gall stones; another is improvements in case ascertainment. 
Acute pancreatitis is fairly uncommon. Our unstandardised incidence rates of 4.6 per 100000 in $1963-74,7.7 / 100000$ in 1975-86, and 10.2/100 000 in 1987-98 are comparable to those reported in earlier English studies. ${ }^{2}{ }^{10} 16{ }^{17}$ Reported rates have tended to be higher in Scotland, ${ }^{518}$ the United States, ${ }^{19}$ Germany, ${ }^{20}$ and the Scandinavian countries ${ }^{81} 22$ than in England, although rates in the Netherlands ${ }^{623}$ have been more comparable.

Although some studies have reported reductions over time in case fatality rates, ${ }^{4-8}$ a large Finnish study found no decrease from the $1980 \mathrm{~s}$ onwards. ${ }^{24}$ The fact that case fatality in our study has not fallen since the 1970 s is no doubt because no major innovations in treatment have been introduced in recent times.

The database was built over many years by Leicester Gill, Glenys Bettley, and Myfanwy Griffith. We thank David Yeates for extraction of data for analysis.

Contributors: MJG and SER designed the study and wrote the manuscript. SER reviewed the literature and undertook the analyses. MJG and SER are guarantors.

Funding: The Research and Development Directorate of the Department of Health funds the Unit of Health Care Epidemiology to undertake research using the database. The database was funded by the former Oxford Regional Health Authority. Competing interests: None declared.

Ethical approval: Oxford Region Data Protection Steering Group and the health authorities' Caldicott Guardians for building the original database. Ethical approval was not needed for analysis of a fully anonymised statistical dataset.

1 O'Sullivan JN, Nobrega FT, Morlock CG, Brown AL Jr, Bartholomew LG Acute and chronic pancreatitis in Rochester, Minnesota, 1940 to 1969. Acute and chronic pancreatitis
Gastroenterology 1972;62:373-9.

2 Corfield AP, Cooper MJ, Williamson RC. Acute pancreatitis: a lethal disease of increasing incidence. Gut 1985;26:724-9.

3 Lankisch PG, Schirren CA, Schmidt H, Schonfelder G, Creutzfeldt W. Etiology and incidence of acute pancreatitis: a 20-year study in a single institution. Digestion 1989;44:20-5.

4 Wilson C, Imrie CW. Changing patterns of incidence and mortality from acute pancreatitis in Scotland, 1961-1985. Br J Surg 1990;77:731-4.

5 McKay CJ, Evans S, Sinclair M, Carter CR, Imrie CW. High early mortality rate from acute pancreatitis in Scotland, 1984-1995. Br J Surg ity rate from $86: 1302-5$.
6 Eland IA, Sturkenboom MJ, Wilson JH, Stricker BH. Incidence and mortality of acute pancreatitis between 1985 and 1995. Scand J Gastroenterol 2000;35:1110-6.

7 Tinto A, Lloyd DA, Kang JY, Majeed A, Ellis C, Williamson RC, Maxwell JD. Acute and chronic pancreatitis-diseases on the rise: a study of hospital admissions in England 1989/90-1999/2000. Aliment Pharmacol Ther 2002;16:2097-105

8 Floyd A, Pedersen L, Nielsen GL, Thorladcius-Ussing O, Sorensen HT. Secular trends in incidence and 30-day case fatality of acute pancreatitis in North Jutland County, Denmark: a register-based study from 1981-2000. Scand J Gastroenterol 2002;37:1461-5.

9 Mann DV, Hershman MJ, Hittinger R, Glazer G. Multicentre audit of death from acute pancreatitis. Br J Surg 1994;81:890-3.

10 Toh SK, Phillips S, Johnson CD. A prospective audit against national standards of the presentation and management of acute pancreatitis in the south of England. Gut 2000;46:239-43.

11 Mero M. Changing aetiology of acute pancreatitis. Ann Chir Gynaecol 1982;71:126-9.

12 Secknus R, Mössner J. Inzidenz- und Prävalenzveränderungen der akuten und chronischen Pankreatitis in Deutschland [Changes in incidence and prevalence of acute and chronic pancreatitis in Germany]. Chirurg 2000;71:249-52

13 Johnson CD, Hosking S. National statistics for diet, alcohol consumption, and chronic pancreatitis in England and Wales, 1960-88. Gut 1991;32:1401-5.

14 National Statistics. Living in Britain: results from the 2000 general household survey. London: Stationery Office, 2001:159.

15 Baker A, Rooney C. Recent trends in alcohol-related mortality, and the impact of ICD-10 on the monitoring of these deaths in England and Wales. Health Stat Q 2003;17:5-14.

16 Trapnell JE, Duncan EH. Patterns of incidence in acute pancreatitis. BMJ 1975;2:179-83.

17 Bourke JB. Variation in annual incidence of primary acute pancreatitis in Nottingham, 1969-74. Lancet 1975;2:967-9.

18 Thomson SR, Hendry WS, McFarlane GA, Davidson AI. Epidemiology and outcome of acute pancreatitis. BrJ Surg 1987;74:398-401.

19 Go VLW. Etiology and epidemiology of pancreatitis in the United States. In: Bradley EL III, ed. Acute pancreatitis: diagnosis and therapy. New York: Raven Press, 1994:235-9.

20 Lankisch PG, Assmus C, Maisonneuve P, Lowenfels AB. Epidemiology of pancreatic diseases in Luneburg county. A study in a defined German population. Pancreatology 2002;2:469-77.

21 Halvorsen FA, Ritland S. Acute pancreatitis in Buskerud county, Norway. Incidence and etiology. Scand J Gastroenterol 1996;31:411-4.

22 Appelros S, Borgstrom A. Incidence, aetiology and mortality rate of acute pancreatitis over 10 years in a defined urban population in Sweden. $\mathrm{BrJ}$ Surg 1999;86:465-70.

23 Tran DD, Van Schilfgaarde R. Prevalence and mortality from acute pancreatitis in the Netherlands during 1971-1990 [abstract]. Digestion 1994;55:342-3.

24 Gronroos JM, Nylamo EI. Mortality in acute pancreatitis in Turku University Central Hospital 1971-1995. Hepatogastroenterology 1999; 46:2572-4.

(Accepted 29 April 2004)

\section{One hundred years ago}

\section{The diminishing birth-rate}

Sir,-The subject of the diminution in the birth-rate has undoubtedly brought to light some ingenious theories, particularly as regards the case of the middle class. But why muscularity in the poor woman should produce such totally different results as the same condition amongst the more refined is not explained. Is it not probable that any attempt at an explanation would demolish the theory entirely? I feel some diffidence in coming forward with yet another hypothesis. But since I have for 25 years practised exclusively amongst the professional class-having neither poor nor wealthy patients-and having since boyhood moved in that society alone, I cannot help thinking that I may have had peculiar advantages of forming an opinion regarding them.

The question I opine is entirely an economic one. There is, as far as I have observed, no loss of virility or fecundity, but children are now universally undesired, mainly from the increasing difficulty in educating them and placing them in life.

To find a girl a suitable husband with a home, or a boy with an avocation suited to a gentleman, will in the near future tax the ingenuity of the most capable mother or father.
When we have realized that we are being made to pay, in order that our coachman's sons may be able to compete against our own sons for daily bread, the contemplation of the situation in front of us must give us pause. Thus it is that many men dread matrimony (notably amongst the clergy) and almost all practise Malthusian methods.

It is my solemn conviction that the professional class, as a distinct order, is being obliterated. In the past the upper class depended on its estates (funded or real), the merchant class upon its capital, the poor on their labour, and the professional class upon its education. The new education legislation has robbed the latter of its patrimony, and there is therefore no sure living for its children.

This is a saddening prospect, for the old refined ways of thought and living, of which this class were the custodians and examplars, are passing away. England will become Germanized or Americanized by this process alone, and the English gentleman, apart from the jeunesse doré, will become as extinct as the British yeoman. - I am, etc.,

Hampstead. (BMJ 1904;i:807) 